\title{
Research on the Hydrophilic Modified of LDPE for the New Biological Suspended Filler
}

\author{
Weijia Kang ${ }^{1}$,jianyun $\mathrm{He}^{2}$, Zhenwen $\mathrm{Liu}^{3}$, XiDan Luo ${ }^{4}$, Chunxian Ye ${ }^{5}$, Hong $\mathrm{He}^{6 *}$, \\ Weimin Yang ${ }^{7}$ and Yumei Ding ${ }^{8}$ \\ ${ }^{12345678}$ Beijing University of Chemical Technology, Beijing China100029 \\ Yinglan Laboratory of Advanced Polymer Processing \\ 2jyhe2009@163.com, “Hehong668@163.com
}

\begin{abstract}
Urban sewage is one of the main pollution sources of the city, which pollute soil, deteriorate the water quality and increase the water shortages and urban load. LDPE is low cost and widely used as the basic material of wastewater treatment, but LDPE's hydrophilic is not good enough to meet the need of suspended filler in wastewater treatment. In this paper the hydrophilic modified of LDPE for the new biological suspended filler was studied and the preparation and processing technique based on LDPE was researched. The hydrophilic and mechanic performance of the hydrophilic modified materials was tested. Results shown that the new type of hydrophilic modified materials has good hydrophilic and meets the demand of urban sewage treatment. The research on the new suspended filler materials has great meaning in solving the problem of urban sewage and recycling.
\end{abstract}

Keywords: LDPE hydrophilic modified; biological suspended filler; grafted master batch; contact angle; wastewater treatment;

\section{Introduction}

Urban sewage is one of the main pollution sources of the city, which pollute the water, soil, deteriorate the water quality and increase the water shortages and urban $\operatorname{load}^{[1-2]}$. Wastewater has big influence on the survival and development of cities. In recent years, much research has been down on urban sewage treatment using the new bio-filler at home and abroad. Japan Engineering and Trading Company ${ }^{[3]}$ has developed RINCLACE biological filler which has been applied in the engineering project. LINPOR filler developed by Germany LindeAG company and CAPTOR biological filler developed by British SIMON-HARTLE have also been widely applied in engineering project and are suitable for high concentration wastewater treatment ${ }^{[4-5]}$.

In china biological filler has also been researched by many researchers, but the research

\footnotetext{
*Corresponding author: jyhe2009@163.com
} 
work mainly focus on the shape, structure, water distribution and gas distribution of the biological filler. There were some studies on biological affinity. An Yan et al ${ }^{[6]}$ modified polyethylene by adding sugars, hydroxyapatite, magnetic powder in ordinary polyethylene to prepare the biological filler. Cheng Jiang et $\mathrm{al}^{[7]}$ modified polyethylene by filled in a small amount of PVA, octadecanoic acid, magnetic particle in ordinary polyethylene to improve the startup speed of microbial bio-film on biological filler.

Some commercial bio-fillers were also appeared in the market, however, most of them are biological inert, non-activation to the microbe, inadequate biological affinity and poor surface wet and cannot provide adequate nutrient source for the microbe to group up, which all affected the efficiency and effectiveness of wastewater treatment.

The hydrophilicity, electrostatic interaction and morphology of the filler's surface have a very significant impact on the formation and attachment of the bio-film. Bacterium usually bring with hydrophilic particles itself, therefore increasing the surface hydrophilicity of the bio-film can accelerate the formation of bio-film; The bacterium's surface generally has negative charge, if the filler's surface has higher positive potential, the bacteria is easy to form on filler's surface. At the same time, the roughness and the amount of small gaps on the filler's surface also have a significant impact on the speed of the formation of the bio-film. Due to LDPE cost low, process simple, it is widely used as the basic material of biological filler, but LDPE's hydrophilic is not good enough to meet the need of bio-film. In this paper the hydrophilic modified of LDPE for the new biological suspended filler was studied to meet the market requirements for high-performance biological suspended filler.

Wastewater is the main water pollution sources.Improper handling will bring a series of ecological and environmental problems which influence and endanger the urban survival and development,pollutethe water and soil, break water balance, deteriorate the water quality, and increase the water shortages and urban load ${ }^{[8-9]}$.

The current level of the sewage treatmentindustry and technologyin our countrystill lags behind the developed countries. The main problems faced include the imperfect sewage treatment materials and process, inadequate facilities, low sewage treatment rate. The main pollutants in urban wastewater include: organic pollutants, ammonia, nitrogen, phosphorus, etc. The main pollutants are generally removed by biological methods.In many biological methods, the studyon the biofilm of urban wastewater treatment has been valued by the world's countries ${ }^{[10]}$.

Hydrophilic suspended filler is the microorganism's vector and the biofilm habitat sites, affecting microbial growth, reproduction, shedding and shape, which have a major impact on the efficiency and effectiveness of wastewater treatment ${ }^{[11]}$.

\section{Materials and Equipment}

\subsection{The raw materials}

LDPE 6100M, LDPE607 Bought from Beijing Yanshan petrochemical company;

Dicumyl peroxide ( DCP ) Bought from Changzhou nord chemical new material co., LTD; LDPE-g-MAH , polymer antistatic agent Laboratory synthesis;

LDPE-g-GMA, polymer antistatic agent Laboratory synthesis;

Cellulose, Zibo FuXin cellulose plant;

Silane coupling agent 151 (A-151 United States united carbon co., LTD);

\subsection{Equipment}

1) Material universal testing machine: Universal testing machine, INSTRON 1185, Instron Corporation. 
2) Video contact angle measuring instrument (OCA20), DATAPHGSICS colloid chemistry company

3) co-rotating twin-screw extruders, $L / D=60: 1, \quad \phi_{\mathrm{m}}=40$, Nanjing KeYa company;

4) Single screw extruder, $\phi_{m}=30$ Weifang EastChina plastic machinery co., LTD;

5) High-speed dispersion machine,SDF-400 ,Sai Ke Long machinery equipment co., LTD. (Chengdu)

\section{Hydrophilic Modified of LDPE for Biological Suspended Filler}

\subsection{Preparation of cellulose master batch}

Cellulose pretreatment: Cellulose was dried at $80{ }^{\circ} \mathrm{C}$ for $2 \mathrm{~h}$, then treated with $2 \%$ silane 151 in High-speed dispersion machine.LDPE607 (25\%) and treated cellulose $(75 \%)$ was Processed by twin-screw extruder, Processing parameters of the cellulose master batch was shown in table1.

Table1 Processing Parameters Of The Cellulose Master Batch

\begin{tabular}{cccccc}
\hline & $\begin{array}{c}\text { Second } \\
\text { district }\end{array}$ & $\begin{array}{c}\text { Four } \\
\text { district }\end{array}$ & $\begin{array}{c}\text { Six } \\
\text { district }\end{array}$ & $\begin{array}{c}\text { Seven } \\
\text { district }\end{array}$ & prow \\
\hline $\begin{array}{c}\text { Setting } \\
\text { temperature } /{ }^{\circ} \mathrm{C} \\
\text { Actual }\end{array}$ & 115 & 135 & 140 & 135 & 135 \\
\begin{tabular}{c} 
temperature $/{ }^{\circ} \mathrm{C}$ \\
\hline
\end{tabular} & 115 & 136 & 139 & 137 & 134 \\
\hline
\end{tabular}

During the processing of cellulose master batch, melt fracture phenomenon, bamboo-like tripe and white crisped appeared in some individual parts. By increasing the processing temperature the melt fracture phenomenon greatly reduced.

\subsection{The preparation of LDPE grafted master batch}

The fomula of the LDPE grafted master batch is shown in table2

Table2 The Fomula Of The Ldpe Grafted Master Batch

\begin{tabular}{cccc}
\hline code & $\begin{array}{c}\text { LDPE6100 } \\
\text { M }\end{array}$ & DCP & additive \\
\hline $1 \#$ & 100 & 0.08 & 2 \\
(HDPE-g-MAH) \\
\hline $2 \#$
\end{tabular}

\subsection{The preparation of hydrophilic LDPE sheet}

The single screw was used to produce the hydrophilic LDPE sheet. The diameter of the single screw was $25 \mathrm{~mm}$ and the mould's wide and thick was $80 \times 0.8 \mathrm{~mm}$. The medial zone temperatures of the extruder was heated to $175-185{ }^{\circ} \mathrm{C}$ before the beginning the processing. The datum of the hydrophilic LDPE sheet is shown in Table 3. 
Table3 The Datum Of The Hydrophilic Ldpe Sheet

\begin{tabular}{llcrrl}
\hline Code & $\begin{array}{l}\text { LDPE } \\
6100 \mathrm{M}\end{array}$ & $\begin{array}{c}\text { Grafting } \\
\text { master batch }\end{array}$ & $\begin{array}{c}\text { cellulose } \\
\text { master } \\
\text { batch }\end{array}$ & $\begin{array}{r}\text { Oleoyl } \\
\text { acid } \\
\text { amine }\end{array}$ & $\begin{array}{c}\text { Grafting } \\
\text { agent }\end{array}$ \\
\hline $1 \#$ & 84 & 10 & 6 & 2 & HDPE-g-EVA \\
\hline $2 \#$ & 79 & 15 & 6 & 2 & HDPE-g-EVA \\
\hline $3 \#$ & 74 & 20 & 6 & 2 & HDPE-g-EVA \\
\hline $4 \#$ & 84 & 10 & 6 & 2 & HDPE-g-MAH \\
\hline $5 \#$ & 79 & 15 & 6 & 2 & HDPE-g-MAH \\
\hline $6 \#$ & 74 & 20 & 6 & 2 & HDPE-g-MAH \\
\hline $7 \#$ & 94 & 0 & 6 & 2 & HDPE-g-EVA \\
\hline $8 \#$ & 94 & 6 & 0 & 2 & HDPE-g-EVA \\
\hline $9 \#$ & 94 & 0 & 6 & 2 & HDPE-g-MAH \\
\hline $10 \#$ & 94 & 6 & 0 & 2 & HDPE-g-MAH \\
\hline After the & & 64 & 6
\end{tabular}

After the medial zone temperature of the extruder decreased to $165-175^{\circ} \mathrm{C}$, the process began. It was founded that the surface of the $1 \#, 2 \#, 3 \#$ sheet almost white, and from $1 \#$ to $3 \#$ the color gradually faded, The surface of the sheet gradually smooth. Among the $1 \#, 2 \#, 3 \#$ sheets, the processing performance of the $2 \#$ is the best. The processing performance of $4 \#, 5 \#, 6 \#$ sheet was not good and much worse than that of $1 \#, 2 \#, 3 \#, 7 \#, 8 \#$. The color of the $4 \#, 5 \#, 6 \#$ sheet was dark yellow with a smell of pungent. The color of the $9 \#$ sheet was yellow and lost its effectiveness, apparently starch because of over heated. The color of the $10 \#$ sheet is white and its surface is very rough.

According to the experiment above, 1\#,2\#,3\#10\# were choiced to do further mechanical test. Table4 was the mechanical test results of the 1\#,2\#,3\#,10\# Hydrophilic LDPE Sheets.

Table4 The Mechanical Results Of The Hydrophilic Ldpe Sheet

\begin{tabular}{cccccccc}
\hline $\begin{array}{l}\text { Sheet } \\
\text { numbers }\end{array}$ & $\begin{array}{l}\text { thickness } \\
/ \mathrm{mm}\end{array}$ & $\begin{array}{l}\text { Tensile } \\
\text { Strength } \\
\text { /Mpa }\end{array}$ & $\begin{array}{l}\text { fracture } \\
\text { stress } \\
\text { /Mpa }\end{array}$ & $\begin{array}{l}\text { Elastic } \\
\text { Modulus } \\
\text { /Mpa }\end{array}$ & $\begin{array}{l}\text { Elongation } \\
\text { at break } \\
\text { /\% }\end{array}$ & $\begin{array}{l}\text { yield } \\
\text { intensity } \\
\text { /Mpa }\end{array}$ & $\begin{array}{l}\text { yield } \\
\text { stress } \\
\text { /N }\end{array}$ \\
\hline $1 \#$ & 0.90 & 26.58 & 26.51 & 109.7 & 469.6 & 17.59 & 107.8 \\
\hline $2 \#$ & 0.90 & 26.78 & 26.57 & 153.1 & 474.0 & 19.08 & 116.1 \\
\hline $3 \#$ & 0.90 & 20.28 & 19.72 & 140.6 & 462.4 & 16.69 & 101.2 \\
\hline $10 \#$ & 0.90 & 21.57 & 21.56 & 160.8 & 374.8 & 12.22 & 74.6 \\
\hline
\end{tabular}

It can be seen from Table 4, at the same situation, 2\# sheet is the best in mechanical properties such as: tensile strength, facture stress, facture extensibility, yield strength, yield stress and roughness also meets the requirement. Therefore $2 \#$ formulate was used to prepare hydrophilic modified suspended filler. 


\subsection{Measurements of water contact angle}

The surface contact angle of the hydrophilic modified suspended filler made by $2 \#$ formulation and the other two brands bio-filler gotten from the market were tested by video contact angle measuring instrument (OCA20), the test results was shown in Table 5.

Table5 The Surface Contact Angle Of The Biological Filler

\begin{tabular}{cc}
\hline code & Average data \\
\hline hydrophilic modified & 48.0 \\
\hline suspended filler Bio-filler1 & 83. \\
\hline suspended filler Bio-fille2 & 89.5 \\
\hline
\end{tabular}

The contact angle of hydrophilic modified suspended filler was low and $46.7 \%$ lower than that of the other two 的 biological fillers gotten from the market. Results indicated that the surface wetting property of the hydrophilic modified suspended filler is good. Cesspool bio film test result shown that the growing speed of the bio-film on the filler surface and the bio-film's thickness is also good, which described that surface wettability of biological filler have a significant impact on the bio-film's attachment and growth property.

\section{Conclusion}

In this paper the new hydrophilic modified biological suspended filler is researched systematically and the processing technique is studied. The hydrophilic and mechanic performance of the suspended filler was tested. Results shown that the new type of hydrophilic modified suspended filler has good hydrophilic and meets the demand of urban sewage treatment system. The hydrophilic modified suspended filler has great meaning and value in solving the problem of urban sewage and recycling.

Since the broad market prospects of the suspended filler, a variety of new suspended fillers born continuously. The development of suspended filler will be mainly focused on two directions, one in structure of the fillerto design more reasonable and more simple and practical filler; the other is in the material to choose the right production of raw materials and disposal to change the surface characteristics of the material,therefore, it is an important task to develop the filler with the character of large surface area,high mechanical strength,biofilmeasy for moving bed biofilm process.

At present, much research has been down to deal with urban sewage in the world to overcome the problem of urban water shortage. And many sewerage treatment systems need to be transformed to meet the requirement of city development. The method of using Bio-film to deal with urban sewage has gotten more attention by the countries of the world. Hydrophilic modified biological suspended filler is one of core technologies in the sewage treatment system which affects the efficiency, energy consuming, stability and reliability of the urban sewerage treatment.

The hydrophilic modified suspended filler has broad market prospects. A variety of new suspended fillers are born continuously. The development of suspended filler will be mainly focused on the two directions, one is to design more reasonable structure of the filler with more simple and more practical structure, and the other is to choose the right raw materials with reasonable surface characteristics. Thus it is important to develop the new type filler with the characters of large surface area, high mechanical strength and bio-film easy moving.

We will further improve the appearance and the treatment effect of the filler to make the filler structure more reasonable, more conducive for microbial hanging and reproduction. 
Further research will be down on the structure, the chemical properties, the shedding mechanism and the activity of the biological filler to increase the surface area ,reduce the cost of suspended filler and to promote microbial growth and reproduction.

\section{References}

1. Honhshu Chen. Current situation of water resources and water pollution control in China [J].Yunnan Environmental Science, 2003, 22: 66-69.

2. Xiaochang Wang, PengkangJin, Hongmei Zhao. Evaluate of Classification and treatment of pollutants in urban domestic sewage [J]. Water supply and drainage, 2004, 30(9): 38-41.

3. YaminLiu ,Haibo Cui, ZhuoliHao. Research progress of application of fillers in biological treatment of wastewater [J]. Chemical engineering and equipment, 2008, 11: 115-116、71.

4. Shefeng Liu. Study on the structure and performance of a novel mobile bed biofilm reactor B-CELL [D]. Jiang Nan University, 2000.

5. SheliCai, JingCai, ZunyuanRui. Mobile bed biofilm reactor and its application [J]. Shanghai Environmental Science, 2004, 23(6): 257-261.

6. Yan An, Jiang Cheng. Effects of magnetic polyethylene fillers on the aerobic biodegradation of phenol wastewater[J]. China pulp and paper, 2007, 27(7): 19-22.

7. Jiang Cheng, Fan Zhang. The influence of the modification of hydrophilic and hydrophilic magnetic properties on the wettability and the performance of the film of polypropylene[J]. Journal of Chemical Indust, 2004, 55(9): 1564-1567.

8. SiqingXia. Pilot study on the removal of organic pollutants and ammonia nitrogen by suspended packing bioreactor [J]. Water supply and drainage, 2000, 126(12): 42-45.

9. QiongWang, qingqunMeng. Application of different fillers in wastewater treatment[J]. Environmental protection and technology, 2009, 15(1): 36-38.

10. XiuchunWang, zhibinDing. Properties of zeolite and its application in water treatment[J]. Journal of PLA University of Science and Technology, Natural Science Edition 2001, 2(4): 74-77.

11. YuefangChen, cunyiSong, junyanZhang,etc. Study on the application of a new type of composite ball filler in low concentration wastewater reclamation and reuse[J]. Techniques and Equipment for Environmental Pollution Control, 2006, 7(8): 72-75. 